\title{
Family Counseling as An Effort to Maintain the Harmony of A Husband Couple Which does not Have Children
}

\author{
Erlina Harahap ${ }^{\mathrm{a}}$, Nurhasanah Pardede ${ }^{\mathrm{b}}$, Ira Widi Astusti ${ }^{\mathrm{c}}$, \\ ${ }^{a}$ Guidance and Counseling Study Program, Faculty of Teacher Training and Education, Muhammadiyah \\ University, South Tapanuli \\ ${ }^{\mathrm{b}}$ Guidance and Counseling Study Program, Faculty of Teacher Training and Education, Muhammadiyah \\ University, South Tapanuli \\ ${ }^{c}$ Guidance and Counseling Study Program, Faculty of Teacher Training and Education, Muhammadiyah \\ University, South Tapanuli. \\ e-mail: erlinan.harahap@um-tapsel.ac.id
}

\begin{abstract}
Every household must have a problem every marriage would want the birth of a child because children can be trusted with a child's home life will be stronger and more harmonious. Therefore couples who are married try to have children because children are seen as important in the family. The value of children for family or parents in everyday life can be known, among others, from the fact that a child is a place where parents express love, children are a source of family happiness, children are often taken into consideration by a husband and wife to cancel the desire to divorce and also where parents depend on various hopes. The purpose of this research is to describe psychological problems, life dynamics, and the efforts made in maintaining family harmony without the presence of children. The research method uses a qualitative approach with a descriptive design while the research informants are taken by purposive sampling. The results of research on psychological problems found the fact the presence of a child is not the main factor of family harmony but there are still many other factors. Some of the efforts that a husband and wife can make in maintaining family integrity, the first is cooperation, the second is trying to please the couple, the third is adoption, the fourth is getting closer to religious activities. The benefits the results of this study are as a basis for implementing family counseling in handling family problems, especially family problems that do not have children.
\end{abstract}

\section{Keywords: Counseling Family; Harmony; Couple; Without Children.}

Abstract: Setiap rumah tangga pasti ada permasalahannya setiap pernikahan pasti menginginkan lahirnya seorang anak, karena anak dapat dipercaya dengan adanya anak kehidupan rumah tangga akan semakin kuat dan harmonis. Oleh karena itu pasangan yang sudah berumah tangga berusaha untuk memiliki anak karena anak di pandang sebagai hal penting dalam berkeluarga. Namun kenyataannya dalam masyarakat tidak semua pasangan suami istri bisa memiliki anak, bahkan ada yang memutuskan pernikahan karena ketidakhadiran anak dalam keluarga. Nilai anak bagi keluarga dalam kehidupan sehari-hari dapat di ketahui antara lain bahwa anak menjadi tempat anak sering dijadikan pertimbangan oleh sepasang suami istri untuk membatalkan keinginan bercerai dan juga tempat orangtua menggantungkan berbagai harapan. Tujuan penelitian ini untuk mendeskripsikan permasalahan psikologis, dinamika kehidupan dan upaya-upaya yang dilakukan dalam mempertahankan keharmonisan keluarga tanpa kehadiran anak. Metode penelitian menggunakan pendekatan kualitatif dengan rancangan deskriptif sedangkan informan penelitian diambil secara purposive sampling. Teknik pengumpulan data digunakan observasi, wawancara dan dokumentasi. Analisis data dalam penelitian ini yaitu mengumpulkan data. Setelah data dipilah kemudian disajkan, terakhir data disimpulkan atau verifikasi hasil. Adapun hasil penelitian tentang permasalahan psikologis yang di temukan kenyataannya kehadiran seorang anak tidak sebagai faktor utama keharmonisan keluarga namun masih banyak faktor lain. Beberapa upaya yang dapat dilakukan pasangan suami istri dalam mempertahankan keutuhan rumah tangga, yang pertama adalah bekerja sama, yang kedua berusaha menyenangkan hati pasangan, ketiga melakukan pengangkatan anak, keempat mendekatkan diri pada kegiatan keagamaan. Manfaat hasil penelitian ini sebagai dasar dalam penerapan konseling keluarga di masyarakat dalam penanganan masalah keluarga khususnya permasalahan keluarga yang belum memiliki anak

DOI : https://dx.doi.org/10.26486/ijagc.v1i2.1292

URL : http://ejurnal.mercubuana-yogya.ac.id/index.php/IJAGC/index

Email :ijagc@mercubuana-yogya.ac.id 


\section{Kata Kunci: Konseling Keluarga; Keharmonisan; Pasangan; Tanpa anak.}

\section{INTRODUCTION}

Every married couple must want to welcome a child into the family. Children are the fruit of a marriage between a husband, so a family without children feels something is lacking. For children to have. Some can overcome difficulties and various efforts and have done so that the couple must accept the year of marriage has not produced baby. The presence of children in the family is an important thing in everyday life that can be known among what is the place where children pour out love, children are a source of family happiness, children are often taken into consideration by families who receive help for the family, help those who are visiting and also a place where parents fight for various hopes, as a lineage connector (Efriani 2017: 2-3).

Happiness in a family is if in a family there is mutual respect, respect and love each other among family members and the creation of tolerance in it. According to Stinnet and deFrain (in Hawari, 1997: 216) the harmony of the family will be realized if each element in the family can function and act as it should and still hold fast to religious values, time together for the family, creating good relationships between family members, mutual respect for fellow family members, families must be close and strong, and prioritize family integrity, have minimal conflict in the family, then harmonious social interaction between elements in the family can be created. A family has a goal, among others, to obtain offspring or the existence of sex drive, economic reasons, reasons for calm, security reasons and even status reasons. Every married couple would crave the presence of a child in the family. Children are the result of a marriage between husband and wife, so that families without children feel something is lacking.

Based on observations and findings, there are several families of married couples who do not yet have children but can still be sincere and steadfast in accepting the shortcomings of their respective spouses even though they understand that one of the goals of marriage is to continue the offspring, in fact not all married couples can have children and even some the family broke the marriage cord because they didn't have children. But this did not happen at the location of the study, there were several couples still surviving in the household. Why did the study sample do it in Batunadua Jae village because in that place several families did not have children.

From the background description and findings, the researchers are interested in researching married couples who do not have children. Therefore to create a more quality and harmonious family, preventive and curative efforts are needed to anticipate various possible problems or problems that are being experienced by couples who have not yet been blessed with children. The existence of family counseling is very helpful as a family defense effort that has not been blessed with children which will ultimately bring benefits to every family in carrying out life during the rapid flow of changes in science and technology today.

\section{METHODS}

This research was designed using a qualitative descriptive design with a phenomenological approach. Characteristics of respondents selected were married couples who did not have children and the age of marriage over two years. Twelve (12) respondents consisted of six (6) pairs of husband and wife.While the criteria for research informants obtained through purposive sampling is the determination of informants based on certain criteria (sangadji, 2010: 132) in this study the research informants were close family, friends, and neighbors.Data collection methods in qualitative research are very diverse and must be adapted to the problem to be studied, in this study researchers used the method of observation, interviews, and documentation.Data analysis in this study uses thematic analysis, which is a process analysis that can be used in almost all qualitative methods and enables the translation 
of symptoms or qualitative information into qualitative data such as the needs of researchers (Boyatzis, in Poerwandari, 2017). Dependability is a concept that can replace the reliability concept proposed by Lincoln \& Gubn in Poerwandari (2017). Through this concept, researchers take into account differences that might occur regarding the phenomenon under study, as well as changes in design as a result of a deeper understanding of the setting under study.

Checking the validity of the data in this study uses triangulation techniques. The triangulation technique used is data triangulation, researcher triangulation, theory triangulation, and method triangulation. Data triangulation is done using different data sources, namely from several informants. Triangulation of researchers conducted by using different evaluators to evaluate the results of research in this case the next of kin. The triangulation of theories is done by using different theories to interpret the same thing. The main theory that will be used is the theory of family counseling. Method triangulation is carried out using different methods to investigate the same thing. The use of the four triangulations is expected to lead to the results of this study can be justified.

Table 1. Parcipant

\begin{tabular}{|c|c|c|c|c|c|}
\hline Number & $\begin{array}{l}\text { Name / } \\
\text { Couple } \\
\text { Initial }\end{array}$ & Age & Religion & Occupation & $\begin{array}{l}\text { Long Of } \\
\text { Married }\end{array}$ \\
\hline \multirow[t]{2}{*}{1} & $\begin{array}{l}\text { SA } \\
\text { (husband) }\end{array}$ & $\begin{array}{l}48 \text { years } \\
\text { old }\end{array}$ & Islam & PNS & 8 years \\
\hline & JN (wife) & 46 years old & Islam & PNS & \\
\hline \multirow[t]{2}{*}{2} & $\begin{array}{l}\text { SA } \\
\text { (husband) }\end{array}$ & 48 years old & Islam & entrepreneur & 4 years \\
\hline & AS (wife) & 45 years old & Islam & Ibu RT & \\
\hline \multirow[t]{2}{*}{3} & $\begin{array}{l}\text { JP } \\
\text { (husband) }\end{array}$ & 41 years old & Islam & Pedagang & 10 years \\
\hline & EM (wife) & 35 years old & Islam & Pedagang & \\
\hline \multirow[t]{2}{*}{4} & $\begin{array}{l}\text { IE } \\
\text { (husband) }\end{array}$ & 33 years old & Islam & Pedagang & 6 years \\
\hline & RS (wife) & 31 years old & Islam & Ibu RT & \\
\hline \multirow[t]{2}{*}{5} & $\begin{array}{l}\text { AH } \\
\text { (husband) }\end{array}$ & 51 years old & Islam & $\begin{array}{l}\text { Pegawai } \\
\text { Swasta }\end{array}$ & 14 years \\
\hline & $\mathrm{NH}$ (wife) & 41 years old & Islam & Ibu RT & \\
\hline \multirow[t]{2}{*}{6} & $\begin{array}{l}\text { AS } \\
\text { (husband) }\end{array}$ & 38 years old & Islam & PNS & 8 years \\
\hline & $\mathrm{N}$ (wife) & 36 years old & Islam & Ibu RT & \\
\hline
\end{tabular}

\section{FINDINGS AND DISCUSSION}

\section{Findings}

Each respondent gives reasons, views and responses that can be used as guidelines for analyzing and explaining how the couple's efforts in maintaining the integrity of the household and trying to resolve the problem with various alternative solutions offered in solving family problems so that the specified respondent can answer the researcher's questions predefined. The age of marriage of a married couple during marriage is between 4 and 14 years.

The husband and wife who do not have children in Batunadua village have different activities in the household, there are couples who are civil servants, there are couples who help their husband sell at the market, there are couples who join her husband in flower gardening, and there are also entrepreneurs selling businesses food. The husband and wife in this study 
help each other in meeting family needs. Each partner in this study had made an effort and treatment as did the SA and US pair who had gone to the doctor but had not produced results. Likewise with JP and EM couples over the age of 10 years of marriage but not yet blessed with children, the families of $\mathrm{AH}$ and $\mathrm{NH}$ couples seem happy and accept the conditions of those who do not have children meaning they accept problems and solve them. While the US couple and the $\mathrm{N}$ couple look fine, friendly, and helpful, so the couple still feels happy even though not blessed with a child.

\section{Strategy for Resolving Problems with Husbands and Wives Who Have No Children.}

From the opinions expressed by UNESCO, a very basic understanding can be drawn that solving problems that occur in a family can be done in two very simple ways, including by conducting preventive and rehabilitation efforts. Both of these methods can be done by the level of problems experienced by the family. Any problems that occur in the family if not resolved as quickly as possible it will become a big problem and is likely to damage the whole family system (Syarqawi, 2017). Further added by (Hadi P. Suhardjo, 2006: 76) in overcoming problems that occur in the family five steps must be passed, including the following:

1. The family must be aware of the situation and define it as a problem.

2. The family decides to try to solve the problem.

3. The family investigates and processes information relevant to effective problem solving.

4. When the chosen solution has been tried the family will evaluate its effectiveness.

5. Either accept the solution or not, the family must return to the second stage to once again decide whether to keep trying to solve the problem or not.

\section{Efforts or Attempts Made in Maintaining the Harmony of Husband and Wife without Children}

Difficult times felt by each partner is when their marriage age begins to enter 3 years. They began to feel anxious and began to feel the pressure both from within themselves and from their own families and many attempts had been made to obtain offspring but were unsuccessful. In maintaining harmony in the household, always solve it together by trying to try to seek medical treatment as well as alternatives to get children and this is where the importance of family counseling for couples to consult with experts and between the closest family.

The efforts made by husband and wife who do not have children in maintaining the integrity of the household.

1. Consult an expert That every problem encountered in living a family life must be sought a solution both from the counselor and in his search, so that he can better understand the problems being faced (Syarqawi, 2017)

2. Cooperation between husband and wife Form of cooperation between husband and wife in earning a living, still maintaining family harmony by solving every problem, because according to the respondent partner there are still other things that make happy for example always together helping with homework so that household harmony is maintained.

According to the couple helped the husband in earning income can reduce the desire to have children (Efriani, 2017):

1. Pleases the couple for example, making a surprise on a couple's birthday, for example giving a gift, cooking a husband's favorite food is a couple's effort in maintaining the integrity of the family. besides praising the couple as an effort in maintaining family harmony.

2. Appointment of children. In this case, it is not adopting children but by caring for siblings, but still meeting every day with biological parents. This will also help couples to forget the disadvantages of not having children. 
3. Draw close to Allah SWT There are several forms of religious orientation by couples to maintain the integrity of the household, including by trying to be sincere in living life, endeavor, surrender and confident in the power of God. This will make the couple more aware that everything that happens is God's will and the absence of a child not a reason not to remember by living it sincerely believing in God's power. This will make the couple more aware that everything that happens is God's will and the absence of children is no reason not to remember God.

\section{Discussion}

In living a family life, always face various changes that will dynamically experience developments that sometimes get positive and negative responses from individuals who face the atmosphere. If the atmosphere and the change get a positive response it will not be a problem, but conversely, if you get a negative response it will become a problem. The harmony of a family is not without problems but every household has a problem both families that have children and families that do not have children all depend on the ability of husband and wife in dealing with it.

The discussion from the results of the above research on families who do not have children that in the process of household travel is not free from problems between husband and wife both coming from outside and from within himself so that each problem will become a journey of household dynamics to find maturity. Every family including families without children must have ways to overcome problems that occur in the household, one of which is through family counseling that is often done by the community by asking for advice or solutions from the immediate family or from professional experts or looking for themselves. Based on the findings and data above, each husband and wife who do not have children try to overcome the problem by working together to make a living, trying to please the couple, adopt children and draw closer to Allah SWT.

\section{CONCLUSION}

From the findings and theories used in discussing the problems of couples who do not have children and the efforts and solutions in solving family problems of couples who do not have children, it can be concluded that the presence of children in a household is not the only factor that makes the family harmonious. In fact, there are families who do not have children but are still happy and the household is still in harmony.

Any problems encountered in living a domestic life must be found a solution either by asking for help from close family, counseling with professionals, or looking for yourself. Every problem in the family, especially those who do not have children, needs to be understood that not all businesses must end successfully even though failing will someday have a special meaning for each family.

Life in the family is a life that is filled with various dynamics and influences so that each family has a unique or specific characteristic in overcoming problems in the family compared to other families. From some of the efforts and efforts made in maintaining the integrity of the couple's household by working together to make a living, trying to please the couple, adopting a child, drawing closer to Allah SWT.

From the various alternatives and solutions that have been offered in solving family problems that do not have children, a conclusion can be drawn that every problem encountered in living a family's life must be solved either by asking for help from the nearest family or counseling with professionals (counselors) or sought individually.

\section{REFERENCES}

Hawari, Dadang. (1960). Al'quran: Ilmu Kedokteran Jiwa dan Kesehatan Jiwa.Jakarta: Dana Bhakti Prima Yasa. 
Basri, Hasan. (1996). Merawat Cinta Kasih.Jakarta: Pustaka Pelajar.

Helmawati. (2014). Pendidikan Keluarga.Jakarta: Media Group.

Hurlock, Elizabeth.B. (1990). Psikologi Perkembangan: Suatu Pendekatan Sepanjang Rentang Kehidupan. (Alih Bahasa Istiwidayati., editor Ridwan Max Sijabat) Edisi Kelima. Jakarta: Penerbit Erlangga.

Yin. Robert K (2002). Studi Kasus, Desain \& Metode. Jakarta: RajaGrafindo Persada.

Arikunto.Suharsimi (2006). Prosedur Penelitian, Suatu Pendekatan Praktik. Jakarta Rineka Cipta.

Irmayani.(2018). Harmonisasi Keluarga Pasangan Suami Istri yang Tidak Memiliki Keturunan di Desa Bangun Jaya Kecamatan Tambusai Utara Kabuoaten Rokan Hulu. Jurnal JOM Fisip Vol.5 No,1April 2018.

Lestari, Sri. (2012). Psikologi Keluarga: Penanaman Nilai dan Penanganan Konflik Dalam Keluarga. Penerbit Kencana Prenada Media Group.

Poerwandari. (2017). Pendekatan Kualitatif Untuk Penelitian Perilaku Manusia. Jakarta: Lembaga Pengembangan Sarana Pengukuran dan Pendidikan Psikologi Fakultas Psikologi Universitas Indonesia.

Moleong, Lexy. (2017). Metodologi Penelitian Kualitatif. Edisi Revisi. Bandung: Penerbit Remaja Rosdakarya.

Willis.S.Sofyan. ((2009). Konseling Keluarga (Family Counseling). Bandung: Alfabeta

Susatya. Jajang (2016). Usaha-usaha Pasangan Suami Istri Pernikahan Usia Dini Dalam Menggapai Keharmonisan Keluaga. Jurnal Magistra No 98 Th XXIX Desember 2016 ISSN 0225-9511.

Erlina, Normita. (2018). Dampak Psikologis Korban Bullying. Jurnal Ristekdik, Bimbingan dan Konseling Vol 4.No1, 2018.

Efriani. (2017). Upaya Keluarga yang Tidak Memiliki Anak Dalam Mempertahankan Keutuhan Rumah Tangganya di Jorong Irian Nagari Ujung Gading Kecamatan Lembah Melintang Kabupaten Pasaman Barat.. Artikel

Syarqawi, Ahmad (2017). Konseling Keluarga, Sebagai Dinamika Dalam Menjalani Kehidupan Keluarga dan Upaya Penyelesaian Masalah. Jurnal Al-Irsyad Vol VII,No 2 Juli-Desember 2017.

Atabik, Ahmad (2013).Konseling Keluarga Islami. (Solusi Problematika Kehidupan Berkeluarga). Jurnal Bimbingan Konseling Islam. 